Provided for non-commercial research and education use. Not for reproduction, distribution or commercial use.

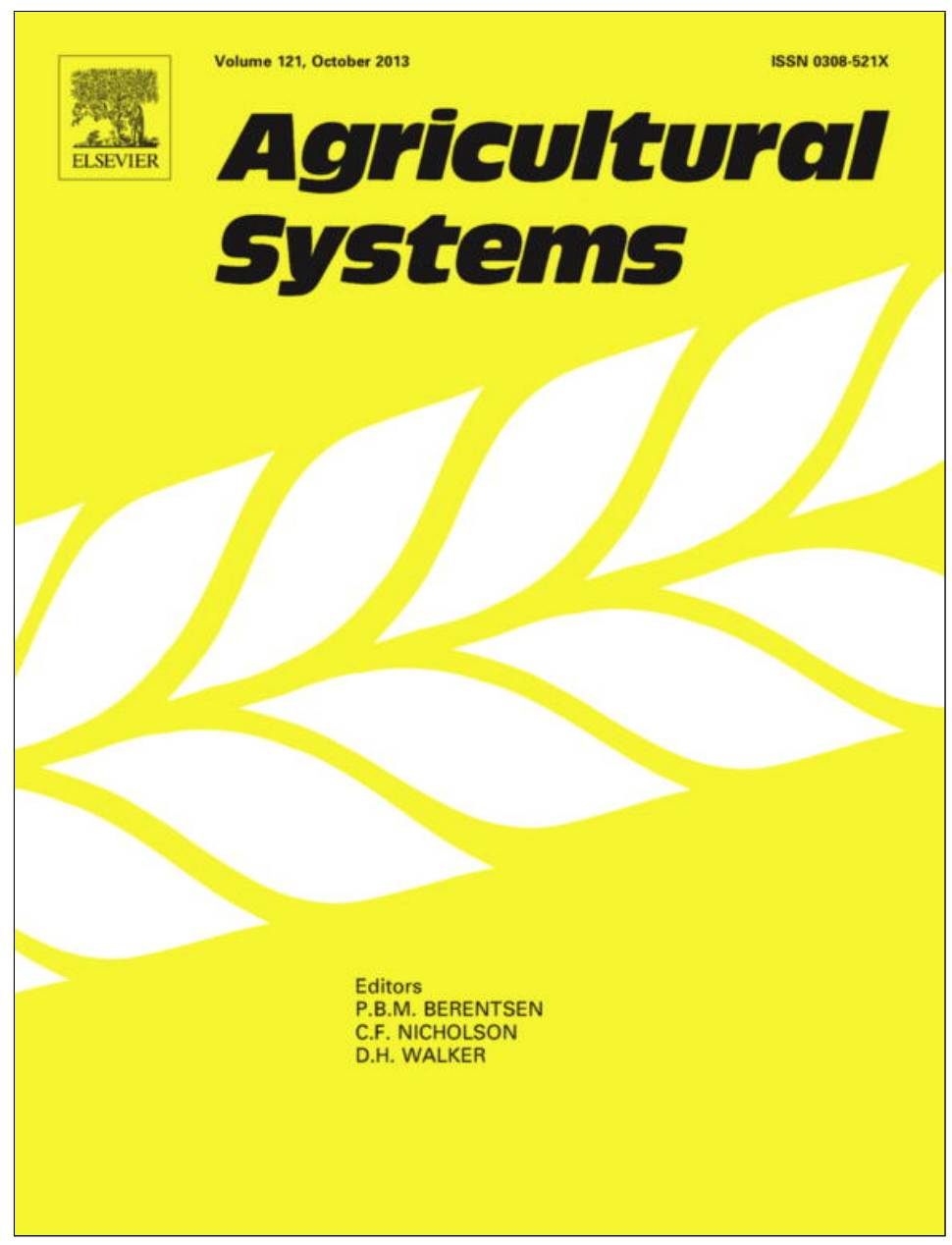

This article appeared in a journal published by Elsevier. The attached copy is furnished to the author for internal non-commercial research and education use, including for instruction at the authors institution and sharing with colleagues.

Other uses, including reproduction and distribution, or selling or licensing copies, or posting to personal, institutional or third party websites are prohibited.

In most cases authors are permitted to post their version of the article (e.g. in Word or Tex form) to their personal website or institutional repository. Authors requiring further information regarding Elsevier's archiving and manuscript policies are encouraged to visit:

http://www.elsevier.com/authorsrights 


\title{
Simulation analysis of factors affecting sorghum yield at selected sites in eastern and southern Africa, with emphasis on increasing temperatures
}

\author{
Neil C. Turner ${ }^{\mathrm{a}, \mathrm{b}, *}$, K.P.C. Rao ${ }^{\mathrm{a}}$ \\ ${ }^{a}$ International Crops Research Centre for the Semi-Arid Tropics (ICRISAT), Eastern and Southern Africa, PO Box 39063, Nairobi 00100, Kenya \\ ${ }^{\mathrm{b}}$ UWA Institute of Agriculture and Centre for Legumes in Mediterranean Agriculture, M080, The University of Western Australia, 35 Stirling Highway, Crawley, WA 6009, Australia
}

\section{A R T I C L E I N F O}

\section{Article history:}

Received 9 July 2012

Received in revised form 31 May 2013

Accepted 5 June 2013

Available online 25 July 2013

\section{Keywords:}

Global warming

Simulation modeling

APSIM-Sorghum

Probability distributions

Higher inputs

Adaptation to climate change

\begin{abstract}
A B S T R A C T
Global warming is widely predicted to decrease crop yields in tropical, sub-tropical and Mediterranean climatic regions as a result of a speeding up of phenological development and shortening of the time to maturity. We used a well-tested simulation model, APSIM-Sorghum, to evaluate the impact of temperatures $+1{ }^{\circ} \mathrm{C},+2{ }^{\circ} \mathrm{C},+3{ }^{\circ} \mathrm{C},+4{ }^{\circ} \mathrm{C}$ and $+5^{\circ} \mathrm{C}$ above current temperatures measured over the past $\sim 50$ years at four sites in eastern and southern Africa, namely, Katumani and Makindu in Kenya, Chitala in Malawi and Beitbridge in Zimbabwe, on the yield, aboveground biomass, transpiration and soil evaporation of short-, medium- and long-duration sorghum [Sorghum bicolor (L.) Moench] cultivars given, 0, 20, 40, and $80 \mathrm{~kg}$ nitrogen $(\mathrm{N}) \mathrm{ha}^{-1}$. When fertilized with $80 \mathrm{~kg} \mathrm{~N} \mathrm{ha}^{-1}$, warming temperatures decreased average yields at Chitala and Beitbridge and yields were unchanged at Makindu and Katumani, but with no added fertilizer average yields increased with increase in temperature at all sites except the hottest and driest site, Beitbridge, where the simulated yields decreased with increasing temperature. Simulation of the changes in soil organic carbon showed that the higher temperatures increased the rate of loss of soil organic carbon and increased nitrogen uptake at all except the driest and hottest site. A micro-dose (20 $\mathrm{kg} \mathrm{N} \mathrm{ha}^{-1}$ ) of added nitrogen increased the simulated yields by an average of $19 \%$ at Beitbridge, 36\% at Makindu, 59\% at Katumani and $72 \%$ at Chitala, considerably greater than any increase from increased temperatures. The use of longer-duration cultivars and lower or higher populations could not consistently be used to overcome any reductions in yield from warming temperatures. We conclude that low-input, small-holder farmers will not immediately have reduced sorghum yields as a consequence of global warming, but micro-dosing with nitrogen fertilizer will significantly increase yields even in the hottest and driest locations.
\end{abstract}

(c) 2013 Elsevier Ltd. All rights reserved.

\section{Introduction}

In Sub-Saharan Africa, 200 million people, or one in every three, are malnourished, while cereal yields are at best growing more slowly than population. Over the past five decades, maize (Zea mays L.) yields have increased from about 1000 to $1500 \mathrm{~kg} \mathrm{ha}^{-1}$ in eastern Africa and from 1200 to $3500 \mathrm{~kg} \mathrm{ha}^{-1}$ in southern Africa, while sorghum [Sorghum bicolor (L.) Moench] yields have increased from $750 \mathrm{~kg} \mathrm{ha}^{-1}$ in both eastern and southern Africa to $1100 \mathrm{~kg} /$ ha in eastern Africa and $1500 \mathrm{~kg} \mathrm{ha}^{-1}$ in southern Africa, much less than the increases in the developed world (FAOSTAT-Agriculture, 2010). Peanut (Arachis hypogaea L.) yields have increased from

\footnotetext{
* Corresponding author at: UWA Institute of Agriculture and Centre for Legumes in Mediterranean Agriculture, M080, The University of Western Australia, 35 Stirling Highway, Crawley, WA 6009, Australia. Tel.: +61 86488 4723; fax: +61 8 64881140.

E-mail address: neil.turner@uwa.edu.au (N.C. Turner).
}

800 to $1800 \mathrm{~kg} \mathrm{ha}^{-1}$ in southern Africa, but only from 550 to $650 \mathrm{~kg} \mathrm{ha}^{-1}$ in eastern Africa (FAOSTAT-Agriculture, 2010). The dual system of commercial and small-holder farmers in Africa, particularly southern Africa, hides the reality that on-farm yields of these staple crops on small-holder farms has remained steady or declined over the same period (World Bank, 2007). The population, rapidly increasing at $2.5 \%$ per annum despite a high death rate from HIV/AIDS (http://esa.un.org/wpp/Excel-Data/population.htm (accessed May 2012)), means that small-holder farmers in subSaharan Africa need to substantially increase food production in the face of climate change.

Studies of recent trends in climate for eastern and southern Africa show that the region has been warming at a rate of $0.5-$ $2.0^{\circ} \mathrm{C}$ per century for the past four decades (Hulme et al., 2001; New et al., 2006; ICPAC, 2007) with high temperature extremes becoming more frequent (New et al., 2006). Changes in rainfall have greater uncertainty, but a detailed analysis of 104 stations across Mozambique, Zambia, Malawi and Zimbabwe showed a 
trend for a delay in consistent rain for planting, a decrease in the number of rain days, an increase in the length of dry spells, and earlier maturity (Tadross et al., 2007). Median temperatures are predicted to rise in eastern and central Africa by about $1^{\circ} \mathrm{C}$ by 2030 (ICPAC, 2007; Lobell et al., 2008) and by $3-4{ }^{\circ} \mathrm{C}$ by the end of the 21st century, while some models predict increases up to $5{ }^{\circ} \mathrm{C}$ in southern and eastern Africa (Christensen et al., 2007). Predictions of future rainfall are less certain. It is generally agreed that rainfall will increase in eastern Africa, particularly in the Great Lakes region, by about $5 \%$ by 2030 (ICPAC, 2007; Lobell et al., 2008 ) and $7 \%$ by the end of the century (Christensen et al., 2007) and likely to decrease by $4 \%$ in southern Africa by the end of the century (Christensen et al., 2007). Of particular concern is the predicted shortening of the crop growing season in southern Africa, particularly the increase in dry spells in the early part of the growing season that delays planting (Tadross et al., 2007).

Analyses of the effects of increasing temperatures on grain yield predict that yields are likely to increase at higher latitudes, but to decrease in the semi-arid and sub-tropical agricultural regions (Jones and Thornton, 2003; Visser and Both, 2005; Cooper et al., 2009; Turner and Meyer, 2011; Turner et al., 2011) as a result of higher temperatures speeding phenological development, and decreasing leaf area, radiation interception and biomass production. However, these predictions are based on data for high-input agricultural crops and the question is whether similar decreases in yield occur with the low-input crops of small-holder farmers. In this paper we use a well-tested simulation model to determine the influence of changes in temperature on yield and factors influencing the yield of sorghum, the staple crop of small-holder farmers in many areas of sub-Saharan Africa, with a range of input levels and management options. We do not include the influence of higher carbon dioxide $\left(\mathrm{CO}_{2}\right)$ concentrations as Cooper et al. (2009) have shown that the so-called $\mathrm{CO}_{2}$ fertilizing effect is small compared to the impact of higher temperatures or water shortage in peanut, and sorghum is a $\mathrm{C}_{4}$ species in which a doubling of $\mathrm{CO}_{2}$ has a much smaller effect on yield than in $C_{3}$ species such as peanut (Cure and Acock, 1986; Seneweera and Norton, 2011). Using the reported $\mathrm{CO}_{2}$ responses of sorghum (Ottman et al., 2001; Prasad et al., 2006) with the Michaelis-Menten rectangular hyperbola method, Hatfield et al. (2008) estimated that the expected $\mathrm{CO}_{2}$ increase over the next 30 years is anticipated to have a negligible effect $(1 \%)$ on sorghum yields. Further, we did not directly include the effects of changes in rainfall as rainfall in eastern Africa is predicted to increase or to remain unchanged, except for a delay in the rains at the start of the growing season in southern Africa (Christensen et al., 2007; Tadross et al., 2007). However, we utilized the variation among seasons to elucidate the effect of rainfall on yields in a changing climate.

\section{Materials and methods}

\subsection{Crop simulation}

We used a simulation model, APSIM-Sorghum (Keating et al., 2003 ) version 7.1, to determine the effects of increasing temperature on the yield and development of sorghum [S. bicolor (L.) Moench]. APSIM-Sorghum simulates the growth of a sorghum crop in a daily time-step on an area basis. Sorghum growth in the model responds to climate (temperature, rainfall and radiation), soil water supply and soil nitrogen, and returns information on the soil water and nitrogen uptake on a daily basis to reset these systems. Information on crop cover is also provided to the soil water component for the calculation of evaporation rates and runoff. APSIMSorghum predicts leaf area development, nitrogen percentage and plant biomass, root depth and biomass, grain yield and nitro- gen content on a daily basis (www.apsim.info/apsim/releases/ Apsim70/Documentation/4\%20Module\%20Reference/Sorghum.htm). It accurately simulates actual crop phenology, yields and yield attributes across a range of soil types, seasons and crop rotations (Ncube et al., 2009; Hansen et al., 2009; Hammer et al., 2010). The model is sufficiently robust to simulate the performance of sorghum under a range of different bio-physical conditions. In the case of Africa, MacCarthy et al. $(2009,2010)$ have tested the performance of the model under different management conditions in semi-arid Ghana where conditions are similar to the sites in this paper. Their studies have indicated that the simulated grain yield of sorghum to both nitrogen and phosphorus application matched well with the observed grain yield with an overall internal coefficient of efficiency of 0.64. Over a range of yields from 500 to $4000 \mathrm{~kg} \mathrm{ha}^{-1}$ at two sites in East Africa, two population levels and two levels of nitrogen fertilizer, the simulated grain yield (SY) was linearly related to the observed grain yield (OY) $\left(S Y=0.95+333, r^{2}=0.55\right)$. Considering the widespread use of the model and its well demonstrated efficiency in simulating water and fertility stresses on sorghum productivity, no attempt was made to calibrate the model for this study. Given that the model is driven by daily weather data, it can be used to evaluate the impacts of temperature and rainfall. Temperature is a key driver of phenological development. Each day the phenology routines calculate thermal time in degree days from 3-hourly air temperatures interpolated from the daily maximum and minimum temperatures. A cardinal mean temperature of $32{ }^{\circ} \mathrm{C}$ is assumed in APSIM-Sorghum, such that time to flowering is reduced linearly from $10^{\circ} \mathrm{C}$ to $32^{\circ} \mathrm{C}$ and then increases with mean temperatures from $32{ }^{\circ} \mathrm{C}$ to $42{ }^{\circ} \mathrm{C}$ at which temperature development stops (Hammer et al., 1993; Carberry et al., 1993). Water availability is determined by the soil characteristics, root growth, initial soil water content, rainfall and evapotranspiration. If the daily demand for water exceeds supply, a water stress factor determined by the supply:demand ratio comes into play and reduces photosynthesis, phenological development and leaf expansion. In each simulation run, it was assumed that weeds, diseases and waterlogging did not affect yields, and as there is no clear regional trend in changes in the diurnal temperature range (New et al., 2006), temperature increases were equally reflected in changes in both the maximum and minimum air temperatures. The key parameters used in the simulation runs are given in Table 1.

\subsection{Locations}

Sites in Kenya, Malawi and Zimbabwe were chosen that had reliable long-run (45-52 years) weather information and measured soil data. The two sites in Kenya were at Katumani with an annual rainfall of $700 \mathrm{~mm}$ and Makindu with an annual rainfall of $620 \mathrm{~mm}$. They were chosen because they had similar annual and growing-season rainfall, but Katumani is cooler than Makindu (Table 2). Chitala in Malawi and Beitbridge in Zimbabwe are both hotter than the two Kenyan sites; Chitala is the wettest site with annual rainfall of $890 \mathrm{~mm}$ while Beitbridge is the driest site with $348 \mathrm{~mm}$ annual rainfall. Table 2 gives the long-term ( $\sim 50$ years) mean maximum and minimum temperatures and mean rainfall for the growing season at each location.

\subsection{Simulating the effect of temperature, fertilization, and plant population}

APSIM-Sorghum was run for each location using the measured climate conditions for the $\sim 50$-year period (referred to as current climate), then re-run with a $1^{\circ} \mathrm{C}, 2^{\circ} \mathrm{C}, 3{ }^{\circ} \mathrm{C}, 4^{\circ} \mathrm{C}$ and $5^{\circ} \mathrm{C}$ increase in temperature on each day during the growth of the sorghum crop, and with no additional nitrogen, 20,40 and $80 \mathrm{~kg} \mathrm{ha}^{-1}$ of 
Table 1

Key soil, crop and management parameters used in the simulation analysis with APSIM-Sorghum. The organic carbon (Org C) fractions given are the total $(\mathrm{T})$, biomass fraction $\left({ }_{\mathrm{B}}\right)$ and inert fraction $\left({ }_{\mathrm{I}}\right)$; the difference between the total and the sum of the fractions in the biomass and the inert is the humic fraction.

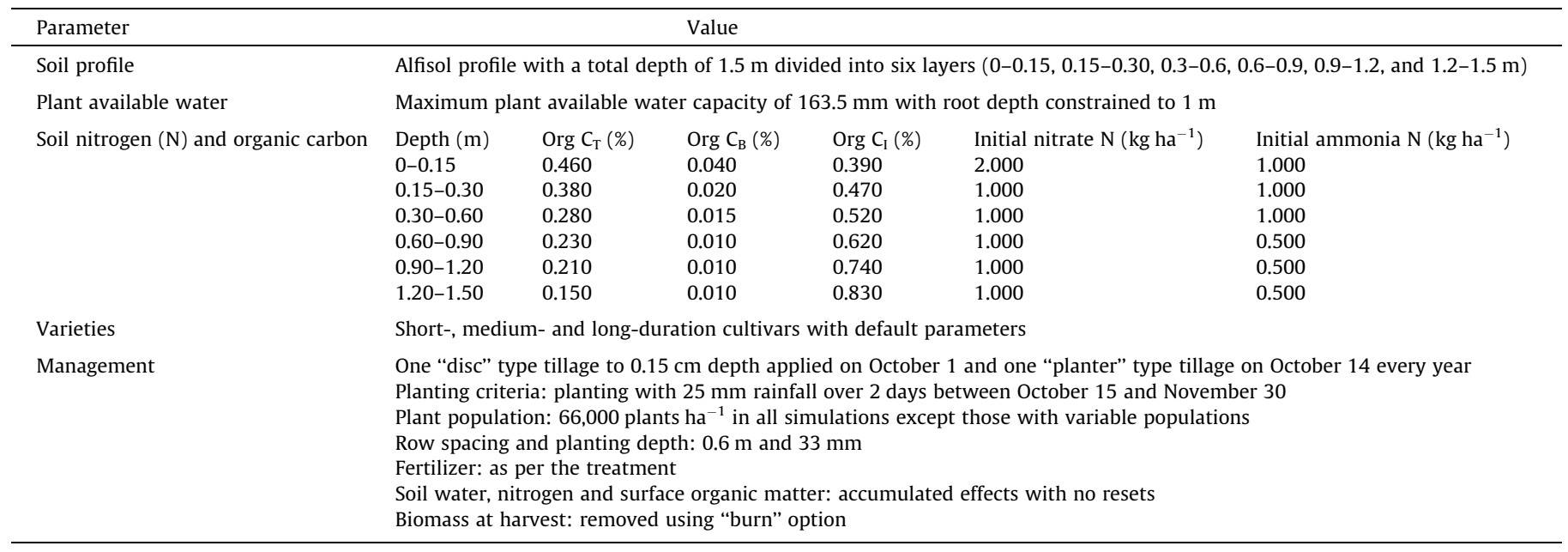

Table 2

Mean maximum and mean minimum growing-season temperatures and mean growing-season rainfall at the four locations in Africa where APSIM-Sorghum was used to evaluate the impact of temperature on the growth and yield of sorghum.

\begin{tabular}{|c|c|c|c|c|}
\hline \multirow[t]{2}{*}{ Location } & \multicolumn{3}{|c|}{ Mean growing season climate } & \multirow{2}{*}{$\begin{array}{l}\text { Period of } \\
\text { record }\end{array}$} \\
\hline & $\begin{array}{l}\text { Max. } \\
\text { temp. }\end{array}$ & $\begin{array}{l}\text { Min. } \\
\text { temp. }\end{array}$ & $\begin{array}{l}\text { Mean rainfall } \\
(\mathrm{mm})\end{array}$ & \\
\hline Makindu, Kenya & 28.6 & 17.1 & 379 & $1959-2004$ \\
\hline Katumani, Kenya & 25.4 & 13.9 & 352 & 1957-2009 \\
\hline Chitala, Malawi & 32.1 & 16.7 & 745 & 1947-1999 \\
\hline Beitbridge, Zimbabwe & 33.2 & 21.4 & 248 & $1951-2001$ \\
\hline
\end{tabular}

nitrogen fertilizer each year at sowing. The simulations were for a short-season sorghum cultivar similar to the one grown at the locations, and additionally for a medium-season and a long-season cultivar. The normal plant population used in the region is 66,000 plants ha $^{-1}$; simulations were also run to determine the influence of reducing the plant population to 50,000 plants ha $^{-1}$ and increasing it to 80,000 plants ha ${ }^{-1}$. The major runs were initiated with nitrogen levels and soil organic carbon levels for each site as given in Table 1 and were not re-initialized each year.

\subsection{Simulated outputs}

APSIM-Sorghum outputs the days to $50 \%$ flowering, days to maturity, biomass, seed yield, soil water, organic carbon and nitrogen content, soil water and nitrogen uptake, soil evaporation and plant transpiration. Daily values and yearly means of these parameters can also be output as required. Mean values of the days to $50 \%$ flowering, days to maturity, total biomass and seed yield for the run of years simulated were calculated, and probability of exceedence values for yield were plotted.

\section{Results}

\subsection{Predicted effects of increasing temperatures on phenology and yield}

At Chitala and Makindu with current climate conditions and no added nitrogen, the early cultivars flowered in about 60 days after sowing (DAS), while the medium-duration cultivars and the longduration cultivars took an additional 10 and 20 days, respectively (Table 3). At Katumani the early cultivar took over 90 days to flow- er and the medium-duration cultivar and long-duration cultivar took an additional 15 and 30 days, respectively, whereas at Beitbridge the early cultivar took 66 days to flower, the medium-duration cultivar took 59 days to flower and the long-duration cultivar flowered in 65 days, the same as the short-duration cultivar (Table 3 ). With climate change, the time to $50 \%$ flowering decreased with every $1{ }^{\circ} \mathrm{C}$ rise in temperature at all four sites and in all three cultivars with different phenologies (Table 3 , only $+1{ }^{\circ} \mathrm{C},+3{ }^{\circ} \mathrm{C}$ and $+5{ }^{\circ} \mathrm{C}$ presented). The time to maturity was also shortened by the warmer temperatures at all sites except Beitbridge where the medium-duration sorghum took longer to mature. At Katumani, a $5{ }^{\circ} \mathrm{C}$ increase in temperature with no added nitrogen reduced the growth period to maturity by $\sim 50$ days (Table 3 ). Despite the decrease in the time to maturity at Makindu, Chitala and Katumani, the yields of the early-, medium- and late-duration sorghum cultivars all increased as the temperature increased given no additional fertilizer, whereas at Beitbridge which has low rainfall, an increase in temperature of $3{ }^{\circ} \mathrm{C}$ and $5{ }^{\circ} \mathrm{C}$ decreased the predicted yield by nearly $20 \%$ and $34 \%$, respectively (Table 3 ). The yields simulated for Katumani, Chitala and Makindu with the current climate are in line with measured and expected yields for the sites and region (Jaetzold et al., 2006).

\subsection{Predicted effects of nitrogen fertilization and increasing temperatures on yield}

At all locations, the application of fertilizer at any level had little effect on the time to maturity, but had a large impact on the biomass and average yield, particularly at the three wetter sites (Table 3). At Chitala and Katumani, addition of $20 \mathrm{~kg} \mathrm{~N} \mathrm{ha}^{-1}$ resulted in an $84 \%$ increase in yields (mean of all duration cultivars) in the current climate, but as the climate warmed the simulated yields increased in Katumani, while they decreased in the shortduration cultivar at Chitala. At Makindu and Beitbridge, where the yield increases from the additional fertilizer were more modest ( $44 \%$ and $14 \%$ across all cultivars, respectively), warmer temperatures had either no effect on yield (Makindu) or yields were reduced (Beitbridge) (Table 3). Increasing the amount of fertilizer to $40 \mathrm{~kg} \mathrm{~N} \mathrm{ha}^{-1}$ (a commercial level of fertilizer) and $80 \mathrm{~kg} \mathrm{~N} \mathrm{ha}^{-1}$ increased yields further at current temperatures, but at Chitala and Beitbridge the warmer temperatures reduced the simulated yields by $\sim 10 \%$ and $\sim 40 \%$ at $+5{ }^{\circ} \mathrm{C}$, while yields were stable at Mak- 
Table 3

Simulated time to 50\% flowering and maturity in days after sowing (DAS), seed yield and total aboveground biomass for short-, medium- and long-season cultivars of sorghum at current temperatures, with 1,3 and $5{ }^{\circ} \mathrm{C}$ increases in temperature and 0, 20, 40 and $80 \mathrm{~kg} \mathrm{ha}^{-1}$ of nitrogen fertilizer at four locations in Africa. Data are averages for $\sim 50$ years of simulation.

\begin{tabular}{|c|c|c|c|c|c|c|c|c|c|c|c|c|c|c|c|c|}
\hline \multirow{2}{*}{$\begin{array}{l}\text { Temperature regime } \\
\left({ }^{\circ} \mathrm{C}\right)\end{array}$} & \multicolumn{4}{|c|}{$0 \mathrm{~kg} \mathrm{ha}^{-1}$ Nitrogen } & \multicolumn{4}{|c|}{$20 \mathrm{~kg} \mathrm{ha}^{-1}$ Nitrogen } & \multicolumn{4}{|c|}{$40 \mathrm{~kg} \mathrm{ha}^{-1}$ Nitrogen } & \multicolumn{4}{|c|}{$80 \mathrm{~kg} \mathrm{ha}^{-1}$ Nitrogen } \\
\hline & $\begin{array}{l}50 \% \\
\text { Flower } \\
\text { (DAS) }\end{array}$ & $\begin{array}{l}\text { Maturity } \\
\text { (DAS) }\end{array}$ & $\begin{array}{l}\text { Yield } \\
\left(\mathrm{kg} \mathrm{ha}^{-1}\right)\end{array}$ & $\begin{array}{l}\text { Biomass } \\
\left(\mathrm{kg} \mathrm{ha}^{-1}\right)\end{array}$ & $\begin{array}{l}50 \% \\
\text { Flower } \\
\text { (DAS) }\end{array}$ & $\begin{array}{l}\text { Maturity } \\
\text { (DAS) }\end{array}$ & $\begin{array}{l}\text { Yield } \\
\left(\mathrm{kg} \mathrm{ha}^{-1}\right)\end{array}$ & $\begin{array}{l}\text { Biomass } \\
\left(\mathrm{kg} \mathrm{ha}^{-1}\right)\end{array}$ & $\begin{array}{l}50 \% \\
\text { Flower } \\
\text { (DAS) }\end{array}$ & $\begin{array}{l}\text { Maturity } \\
\text { (DAS) }\end{array}$ & $\begin{array}{l}\text { Yield } \\
\left(\mathrm{kg} \mathrm{ha}^{-1}\right)\end{array}$ & $\begin{array}{l}\text { Biomass } \\
\left(\mathrm{kg} \mathrm{ha}^{-1}\right)\end{array}$ & $\begin{array}{l}50 \% \\
\text { Flower } \\
\text { (DAS) }\end{array}$ & $\begin{array}{l}\text { Maturity } \\
\text { (DAS) }\end{array}$ & $\begin{array}{l}\text { Yield } \\
\left(\mathrm{kg} \mathrm{ha}^{-1}\right)\end{array}$ & $\begin{array}{l}\text { Biomass } \\
\left(\mathrm{kg} \mathrm{ha}^{-1}\right)\end{array}$ \\
\hline \multicolumn{17}{|l|}{ Chitala } \\
\hline \multicolumn{17}{|l|}{ Short duration } \\
\hline Current & 61.5 & 108 & 1660 & 4155 & 59.3 & 107 & 3022 & 6549 & 59.3 & 107 & 3799 & 7554 & 59.8 & 107 & 4803 & 8938 \\
\hline+1 & 58.4 & 105 & 1680 & 4117 & 56.3 & 103 & 2893 & 6372 & 56.8 & 103 & 3706 & 7290 & 57.3 & 104 & 4769 & 8691 \\
\hline+3 & 55.3 & 100 & 1716 & 4071 & 54.2 & 99 & 2907 & 6141 & 54.4 & 99 & 3642 & 7067 & 54.8 & 100 & 4683 & 8450 \\
\hline+5 & 55.3 & 100 & 1759 & 4131 & 54.5 & 99 & 2913 & 6214 & 54.8 & 100 & 3602 & 7205 & 55.1 & 100 & 4425 & 8476 \\
\hline \multicolumn{17}{|l|}{ Medium duration } \\
\hline Current & 71.6 & 119 & 1503 & 4434 & 67.6 & 115 & 2858 & 7158 & 66.9 & 114 & 4165 & 9196 & 67.1 & 114 & 5301 & 10,612 \\
\hline+1 & 67.4 & 113 & 1573 & 4446 & 64.3 & 110 & 2900 & 7062 & 63.8 & 110 & 4107 & 8905 & 64.0 & 110 & 5225 & 10,259 \\
\hline+3 & 63.5 & 109 & 1651 & 4466 & 61.2 & 106 & 2915 & 6923 & 61.0 & 106 & 3997 & 8549 & 61.2 & 106 & 5118 & 9871 \\
\hline+5 & 63.3 & 108 & 1729 & 4554 & 61.3 & 106 & 2933 & 6919 & 61.0 & 106 & 3912 & 8471 & 61.6 & 106 & 4821 & 9672 \\
\hline \multicolumn{17}{|l|}{ Long duration } \\
\hline Current & 83.7 & 131 & 1347 & 4713 & 77.9 & 125 & 2432 & 7193 & 74.7 & 122 & 3905 & 9862 & 75.0 & 122 & 5541 & 12,279 \\
\hline+1 & 78.4 & 124 & 1433 & 4736 & 73.5 & 120 & 2528 & 7165 & 71.1 & 117 & 3922 & 9646 & 71.5 & 118 & 5412 & 11,796 \\
\hline+3 & 73.0 & 118 & 1548 & 4778 & 69.3 & 114 & 2677 & 7159 & 67.6 & 113 & 3894 & 9327 & 68.4 & 113 & 5166 & 11,050 \\
\hline+5 & 72.5 & 117 & 1639 & 4876 & 69.2 & 114 & 2725 & 7179 & 67.7 & 112 & 3767 & 9097 & 69.0 & 114 & 4773 & 10,438 \\
\hline \multicolumn{17}{|l|}{ Makindu } \\
\hline \multicolumn{17}{|l|}{ Short duration } \\
\hline Current & 59.2 & 105 & 1736 & 4132 & 57.4 & 105 & 2565 & 5821 & 54.4 & 106 & 2942 & 6368 & 52.6 & 107 & 3051 & 6714 \\
\hline+1 & 54.5 & 100 & 1792 & 4055 & 52.8 & 100 & 2579 & 5620 & 53.7 & 101 & 3004 & 6168 & 47.9 & 102 & 3175 & 6558 \\
\hline+3 & 48.4 & 93 & 1843 & 3878 & 46.8 & 93 & 2579 & 5252 & 48.3 & 94 & 3041 & 5796 & 48.6 & 96 & 3268 & 6193 \\
\hline+5 & 46.3 & 91 & 1856 & 3777 & 44.8 & 92 & 2524 & 4990 & 46.9 & 93 & 2937 & 5508 & 48.4 & 94 & 3086 & 5783 \\
\hline \multicolumn{17}{|l|}{ Medium duration } \\
\hline Current & 70.1 & 115 & 1537 & 4409 & 65.4 & 115 & 2248 & 6261 & 57.6 & 115 & 2574 & 6919 & 54.9 & 117 & 2845 & 7372 \\
\hline+1 & 64.0 & 109 & 1644 & 4356 & 61.4 & 110 & 2337 & 6109 & 51.4 & 108 & 2656 & 6700 & 53.2 & 110 & 2919 & 7124 \\
\hline+3 & 56.5 & 101 & 1753 & 4225 & 51.2 & 100 & 2391 & 5773 & 52.6 & 102 & 2811 & 6404 & 49.6 & 102 & 3069 & 6742 \\
\hline+5 & 52.3 & 99 & 1778 & 4133 & 51.6 & 98 & 2340 & 5478 & 47.4 & 98 & 2682 & 5986 & 47.0 & 100 & 2943 & 6322 \\
\hline \multicolumn{17}{|l|}{ Long duration } \\
\hline Current & 82.8 & 127 & 1319 & 4614 & 63.1 & 123 & 1823 & 6334 & 66.8 & 127 & 2265 & 7398 & 64.5 & 128 & 2561 & 7883 \\
\hline+1 & 75.9 & 120 & 1419 & 4552 & 62.2 & 117 & 1913 & 6205 & 61.1 & 119 & 2334 & 7122 & 54.5 & 119 & 2604 & 7582 \\
\hline+3 & 59.2 & 109 & 1553 & 4420 & 59.7 & 109 & 2034 & 5880 & 52.9 & 111 & 2443 & 6655 & 52.6 & 112 & 2720 & 7105 \\
\hline+5 & 56.6 & 105 & 1565 & 4286 & 52.5 & 104 & 2008 & 5585 & 50.0 & 106 & 2335 & 6214 & 51.8 & 107 & 2592 & 6595 \\
\hline
\end{tabular}

Katumani

Short duration Current

$+1$

+3
+5

\begin{tabular}{|c|c|c|c|c|c|c|c|c|c|c|c|c|c|c|c|}
\hline 92.5 & 145 & 1195 & 4086 & 89.5 & 143 & 2368 & 6700 & 79.4 & 142 & 2584 & 7369 & 79.3 & 145 & 2627 & 7719 \\
\hline 63.1 & 109 & 1588 & 4166 & 65.4 & 113 & 2554 & 6156 & 53.9 & 110 & 2630 & 6405 & 53.7 & 112 & 2757 & 6655 \\
\hline 53.1 & 98 & 1710 & 4011 & 52.7 & 99 & 2507 & 5634 & 51.0 & 100 & 2787 & 5999 & 48.5 & 100 & 2956 & 6248 \\
\hline
\end{tabular}


Medium duration Current 106.8
94.5
74.9
61.9

$\begin{array}{rrrrr}159 & 1029 & 4363 & 105.8 & 15 \\ 144 & 1133 & 4402 & 90.8 & 143 \\ 121 & 1406 & 4447 & 77.1 & 125 \\ 107 & 1581 & 4339 & 63.7 & 111\end{array}$

$\begin{array}{ll}159 & 1930 \\ 143 & 2021 \\ 125 & 2217 \\ 111 & 2329\end{array}$

$\begin{array}{lll}1930 & 6969 & 94.3 \\ 2021 & 6852 & 78.3 \\ 2217 & 6550 & 64.2 \\ 2329 & 6197 & 54.4\end{array}$

Long duration

Current

$\begin{array}{llll}121.5 & 175 & 933 & 4729\end{array}$

$119.8 \quad 173$

$\begin{array}{lll}1546 & 6964 & 113.8\end{array}$

$\begin{array}{ll}78.3 & 142 \\ 64.2 & 122 \\ 54.4 & 109\end{array}$

$\begin{array}{ll}159 & 2287 \\ 142 & 2 \\ 122 & 2368 \\ 109 & 2417\end{array}$

$\begin{array}{llllll}2287 & 8162 & 83.3 & 158 & 2470 & 8544 \\ 2148 & 7658 & 76.9 & 144 & 2467 & 8149 \\ 2368 & 7118 & 59.7 & 123 & 2534 & 7388 \\ 2417 & 6503 & 57.0 & 110 & 2839 & 6973\end{array}$

$+$

$\begin{array}{rrrrr}108.4 & 158 & 1014 & 4765 & 110.2 \\ 89.5 & 135 & 1197 & 4706 & 87.4 \\ 74.8 & 120 & 1423 & 4625 & 67.7\end{array}$

$\begin{array}{ll}87.4 & 136 \\ 67.7 & 121\end{array}$

Beitbridge

Short duration Current

+1
+3
+5

Medium duration

Current

+1
+3

+3
+5

Long duration

Current

$423 \quad 4625$

$\begin{array}{ll}66.4 & 117 \\ 66.0 & 118 \\ 57.7 & 121 \\ 55.4 & 126\end{array}$

$\begin{array}{llll}795 & 2479 & 49.2 & 124 \\ 767 & 2392 & 50.2 & 121 \\ 641 & 2205 & 43.6 & 121 \\ 510 & 2014 & 33.7 & 120\end{array}$

124
121
121
120

$\begin{array}{llll}899 & 2985 & 42.2 & 12 \\ 838 & 2842 & 37.5 & 12 \\ 740 & 2634 & 45.7 & 12 \\ 549 & 2319 & 34.6 & 12\end{array}$

122
120
121
121

$966 \quad 3044 \quad 45.2$

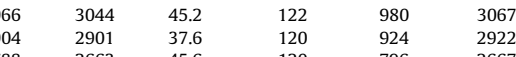

$\begin{array}{llllll}788 & 2663 & 45.6 & 120 & 796 & 2622\end{array}$

$\begin{array}{llllll}58.8 & 134 & 671 & 2598 & 44.8 & 137\end{array}$

$\begin{array}{lllll}137 & 782 & 3158 & 43.6 & 138 \\ 136 & 767 & 3040 & 43.4 & 136 \\ 135 & 690 & 2781 & 39.9 & 134 \\ 137 & 533 & 2510 & 42.6 & 139\end{array}$

$\begin{array}{lllllll}138 & 874 & 3332 & 42.7 & 138 & 895 & 3351\end{array}$

$\begin{array}{llllll}846 & 3189 & 42.0 & 136 & 865 & 3187 \\ 721 & 2882 & 39.8 & 135 & 745 & 2918\end{array}$

$\begin{array}{lllll}54.0 & 133 & 573 & 2290 & 40.1 \\ 50.5 & 141 & 457 & 2130 & 43.9\end{array}$

$+1$

$+3$

$\begin{array}{ll}65.4 & 150 \\ 63.7 & 150 \\ 59.9 & 153 \\ 46.6 & 152\end{array}$

$\begin{array}{lll}593 & 2665 & 38 \\ 564 & 2536 & 40 \\ 481 & 2375 & 41 . \\ 389 & 2199 & 38\end{array}$

$38.6 \quad 152$

$\begin{array}{lll}679 & 3241 & 38 \\ 673 & 3137 & 43.5\end{array}$

$\begin{array}{llllllll}38.3 & 153 & 749 & 3409 & 38.4 & 154 & 791 & 3496\end{array}$

$\begin{array}{llllllll}43.5 & 152 & 728 & 3263 & 43.9 & 153 & 779 & 3360 \\ 40.7 & 151 & 651 & 2997 & 41.1 & 152 & 673 & 3033 \\ 36.9 & 155 & 476 & 2694 & 36.7 & 155 & 473 & 2669\end{array}$

$453 \quad 2586$

155

$473 \quad 2669$


indu and continued to increase at Katumani as temperatures increased (Table 3 ).

The data in Table 3 are the averages for 45-52 years and do not reveal differences among years. Therefore we plotted the annual yields of sorghum as probability distributions to understand the variation in yields and the influence of rising temperatures on these yields. We first evaluated the influence of rising temperatures on the simulated yields of sorghum with no fertilizer, as currently used by small-holder farmers, and with $40 \mathrm{~kg} \mathrm{~N} \mathrm{ha}^{-1}$, that is with a commercial use of fertilizer. At Chitala, yields of the current short-duration cultivar varied over the 52 years from $500 \mathrm{~kg} \mathrm{ha}^{-1}$ to $3800 \mathrm{~kg} \mathrm{ha}^{-1}$ with no additional fertilizer, and increasing temperatures as high as $5^{\circ} \mathrm{C}$ had little effect on yields in $50 \%$ of years (Fig. 1). In the better years when yields were above $1500 \mathrm{~kg} \mathrm{ha}^{-1}$, rising temperatures increased yields by a maximum of $400 \mathrm{~kg} \mathrm{ha}^{-1}$. The application of a commercial-farm level of $40 \mathrm{~kg} \mathrm{~N} \mathrm{ha}^{-1}$ markedly increased the simulated sorghum yields to $2800-4500 \mathrm{~kg} \mathrm{ha}^{-1}$ over the same years with the current climate, but in all years except the wettest $10 \%$ of years, warmer temperatures decreased the yields by up to $400 \mathrm{~kg} \mathrm{ha}^{-1}$ (Fig. 1).

We then simulated the influence of a $3{ }^{\circ} \mathrm{C}$ rise in temperature on yields with a modest $\left(20 \mathrm{~kg} \mathrm{ha}^{-1}\right)$ increase in fertilizer nitrogen compared with the effect with the zero level of additional fertilizer used by small-holder farmers. At Makindu, with no additional fertilizer, a $3{ }^{\circ} \mathrm{C}$ rise in temperature increased sorghum yields of the current short-duration cultivar in almost all years except the exceptionally wet and productive years when yields were above $3300 \mathrm{~kg} \mathrm{ha}^{-1}$ (Fig. 2). However, with a micro-dose of $20 \mathrm{~kg} \mathrm{~N} \mathrm{ha}^{-1}$, a $3{ }^{\circ} \mathrm{C}$ rise in temperature increased yields in $40 \%$ of years when the yields were below the median, but decreased yields in about $40 \%$ of years when the yields were above the median yield; again the exceptionally wet years when yields were above $3600 \mathrm{~kg} \mathrm{ha}^{-1}$, yields were similar to those at current temperatures (Fig. 2). However, the small increase in fertilizer increased sorghum yields significantly in all but the poorest $10 \%$ of years when yields at $0 \mathrm{~kg} \mathrm{~N} \mathrm{ha}^{-1}$ were about $1000 \mathrm{~kg} \mathrm{ha}^{-1}$ (Fig. 2). The increase in fertilizer use, however, did increase crop failures (yields less than $200 \mathrm{~kg} \mathrm{ha}^{-1}$ resulted in $0 \mathrm{~kg} \mathrm{ha}^{-1}$ harvested) in $2.5 \%$ of seasons at both current temperatures and with a $3{ }^{\circ} \mathrm{C}$ rise in temperature (Fig. 2).

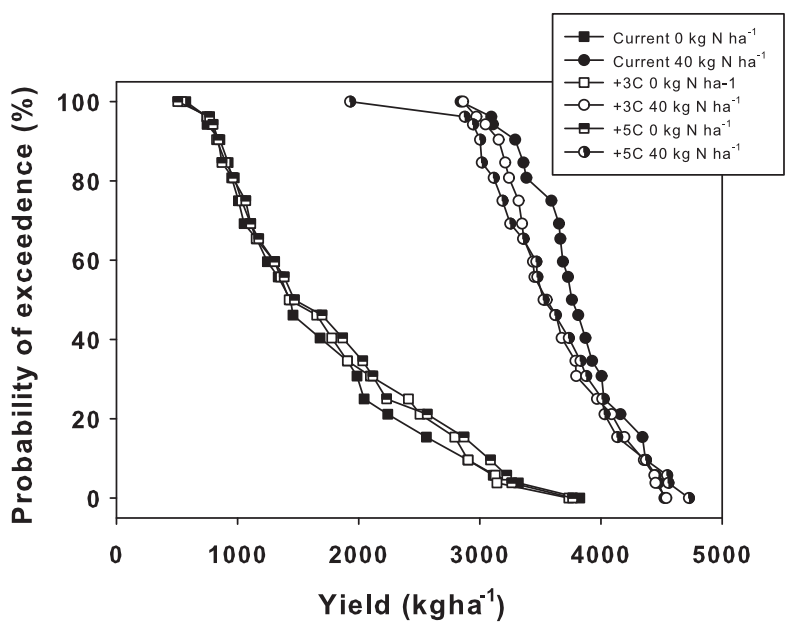

Fig. 1. The influence of a $3{ }^{\circ} \mathrm{C}$ (open symbols) and $5{ }^{\circ} \mathrm{C}$ (half-open symbols) rise in temperature above the current temperatures (closed symbols) on the simulated yields of a short-duration cultivar of sorghum over 52 years at Chitala given 0 (squares) or 40 (circles) $\mathrm{kg} \mathrm{N} \mathrm{ha}^{-1}$. Both the maximum and minimum temperatures were increased by $3{ }^{\circ} \mathrm{C}$ and $5{ }^{\circ} \mathrm{C}$ above the current values on each day from sowing to maturity.

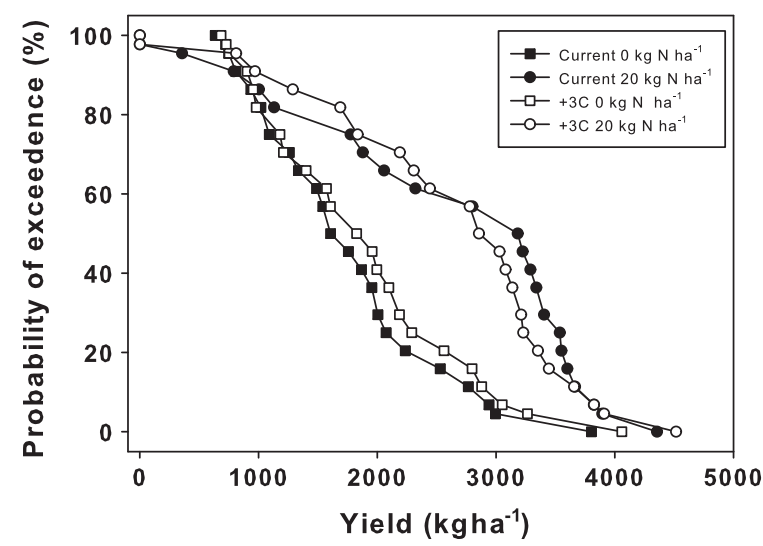

Fig. 2. The influence of a $3{ }^{\circ} \mathrm{C}$ rise (open symbols) in temperature above the current temperatures (closed symbols) on the simulated yields of a short-duration cultivar of sorghum over 45 years at Makindu given 0 (squares) or 20 (circles) $\mathrm{kg} \mathrm{N} \mathrm{ha}^{-1}$. Both the maximum and minimum temperatures were increased by $3{ }^{\circ} \mathrm{C}$ above the current values on each day from sowing to maturity.

\subsection{Predicted effects of phenology, fertilization and increasing temperatures on yield}

The speeding up of development induced by the higher temperatures observed at all sites except Beitbridge and the decrease in mean yield at higher temperatures in the fertilized sorghum (Table 3 ), can be counterbalanced by using late-duration cultivars (Table 3). When we compared the distribution of yields over the 52 years at Chitala with a $3{ }^{\circ} \mathrm{C}$ rise in temperature with no additional nitrogen, the medium- and long-duration cultivars had similar yields to the short-duration cultivar in the $50 \%$ of years when yields were below the median and lower yields in the $50 \%$ of years when yields were above the median (Fig. 3 ). The modest increase in nitrogen application of $20 \mathrm{~kg} \mathrm{~N} \mathrm{ha}^{-1}$ increased yields at Chitala and using a medium-duration cultivar rather than a short-duration cultivar reduced yields in $50 \%$ of years, but increased yields in the wetter years when yields were above $3500 \mathrm{~kg} \mathrm{ha}^{-1}$ (Fig. 3). With the application of the high level of fertilizer of $80 \mathrm{~kg} \mathrm{~N} \mathrm{ha}^{-1}$, the use of later-flowering cultivars increased yields in $85 \%$ of years and was only detrimental to yield when yields were below $4500 \mathrm{~kg} \mathrm{ha}^{-1}$ (Fig. 3).

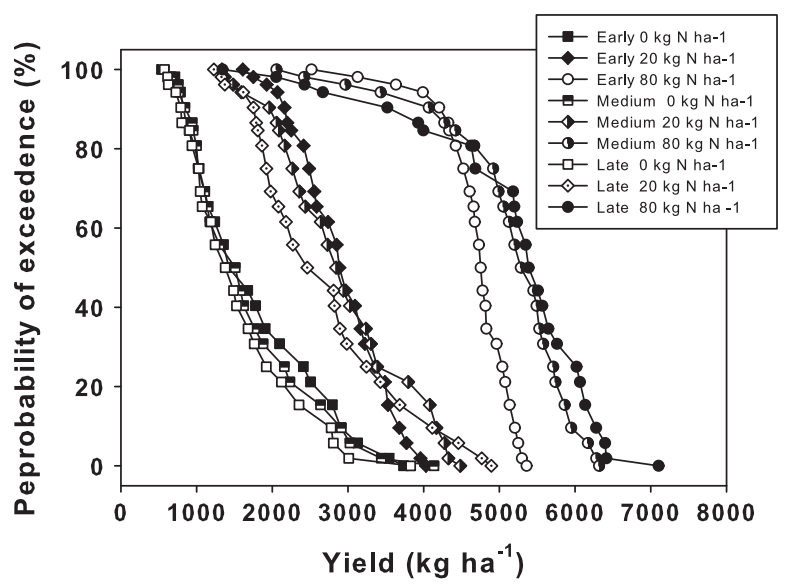

Fig. 3. The influence of a short-duration cultivar (early), a medium-duration cultivar (medium) and a long-duration cultivar (late) on the simulated yields of sorghum over 52 years at Chitala given 0 (squares), 20 (diamonds) and 80 (circles) $\mathrm{kg} \mathrm{N} \mathrm{ha}{ }^{-1}$ and with a $3{ }^{\circ} \mathrm{C}$ rise in temperature above the current temperatures. Both the maximum and minimum temperatures were increased by $3{ }^{\circ} \mathrm{C}$ above the current values on each day from sowing to maturity. 
3.4. Changes in soil evaporation and crop transpiration with increasing temperatures

We used APSIM-Sorghum to explore the water use by the crop in the various treatments. With current practice and a short-duration cultivar, soil evaporation varied from $73 \%$ to $80 \%$ of total evapotranspiration at the four sites (Table 4). With a temperature rise of $3{ }^{\circ} \mathrm{C}$, the proportion of water lost by transpiration increased and the amount of water lost by soil evaporation decreased at the three sites where yields increased, but was unchanged at Beitbridge where yields decreased (Table 4). The addition of $40 \mathrm{~kg} \mathrm{~N} \mathrm{ha}^{-1}$ increased the transpiration by the crop at all sites with little change in soil evaporation, so that the proportion of total evapotranspiration lost as soil evaporation decreased from $73-80 \%$ to $58-71 \%$ at current temperatures (Table 4 ). The addition of fertilizer clearly increased the proportion of the total evapotranspiration that was used in transpiration rather than being lost by soil evaporation.

Using longer season cultivars also increased the transpiration by the sorghum crop at all four sites and at the wetter sites increased the soil evaporation (Table 4). One of the consequences of the higher temperatures shortening the growing season was that it reduced the access to late rains and reduced the overall evapotranspiration of the sorghum at the wetter sites of Katumani and Makindu, but not at Beitbridge and Chitala. For example, at Katumani where the growth of the crop was shortened by about 1 month by a $3{ }^{\circ} \mathrm{C}$ rise in temperature, on average $86 \mathrm{~mm}$ of rain fell in that month. The question is whether longer-duration cultivars can make better use of the total seasonal rainfall in the warmer temperatures associated with climate change. The simulation suggests that the longer-duration cultivars were not able to take full advantage of the water left in the profile and any subsequent rain. For example, at Katumani the total evapotranspiration for sorghum grown with no additional fertilizer decreased from $283 \mathrm{~mm}$ to $241 \mathrm{~mm}$ with a $3^{\circ} \mathrm{C}$ rise in temperature. Despite an additional $86 \mathrm{~mm}$ of rain in the 30 days after the short-duration crop matured, the evapotranspiration of the med- ium-duration cultivar was $258 \mathrm{~mm}$, higher than the short-duration cultivar at the same temperature rise, but not as high as the $283 \mathrm{~mm}$ of the short-duration cultivar at the current temperature (Table 4). However, at Chitala where the $\operatorname{crop}\left(0 \mathrm{~kg} \mathrm{~N} \mathrm{ha}^{-1}\right)$ with a $3{ }^{\circ} \mathrm{C}$ rise in temperature matured 8 days earlier and Makindu where it matured 12 days earlier, total evapotranspiration was not decreased or decreased only $9 \mathrm{~mm}$, and using a medium-duration cultivar increased total evapotranspiration, but not yield (Table 3). This suggests that use of longer-duration cultivars cannot compensate for rising temperatures and shorter maturity as the temperatures rise, presumably because at the higher temperatures the transpiration efficiency of the crops is lower.

\subsection{Predicted changes in soil organic carbon and nitrogen uptake by the crop with increasing temperatures}

One possible reason for the increase with temperature in the simulated sorghum yields with current farming practice was the liberation of nitrogen from the soil microbial biomass. The mean soil organic carbon levels in the top $0.15 \mathrm{~m}$ of the soil at Katumani are $0.46 \%$ (Okwach and Simiyu, 1999). The organic carbon percentage decreased with depth as a result of a decrease in the biologically-active fraction in the microbial biomass and the humic fraction, while the inert fraction of the organic carbon increased with depth (Table 1 ). Using the $0.46 \%$ organic carbon observed at Katumani as a starting value for all locations, the decrease in soil organic carbon at the four locations was simulated by APSIM. Over the 52 years at Katumani, the soil organic carbon decreased at a rate of $0.028 \%$ decade $^{-1}$ when temperatures were $5{ }^{\circ} \mathrm{C}$ higher than the current temperature, compared to $0.021 \%$ decade $^{-1}$ at current temperatures. This can be seen in Fig. 4 where the decrease in organic carbon with current, $+1{ }^{\circ} \mathrm{C},+3{ }^{\circ} \mathrm{C}$, and $+5^{\circ} \mathrm{C}$ temperatures is plotted for the four locations. The rate of decrease in organic carbon was greatest at the wettest site, Chitala, and least at the driest site, Beitbridge, while the impact of the increase in temperature was largest at Katumani, the coolest site, and negligible at the driest and hottest site, Beitbridge. We also simulated the changes in

Table 4

Simulated plant transpiration $(T)$ and soil evaporation $(E)$ for short-, medium-, and long-season cultivars of sorghum at current temperatures, with 1 , 3 and $5{ }^{\circ} \mathrm{C}$ increases in temperature and 0 and $40 \mathrm{~kg} \mathrm{ha}^{-1}$ of nitrogen fertilizer at four locations in Africa. Data are averages for $\sim 50$ years of simulation.

\begin{tabular}{|c|c|c|c|c|c|c|c|c|c|c|c|c|}
\hline \multirow[t]{3}{*}{ Temperature regime $\left({ }^{\circ} \mathrm{C}\right)$} & \multicolumn{4}{|c|}{ Short duration } & \multicolumn{4}{|c|}{ Medium duration } & \multicolumn{4}{|c|}{ Long duration } \\
\hline & \multicolumn{2}{|c|}{$0 \mathrm{~kg} \mathrm{~N} \mathrm{ha}^{-1}$} & \multicolumn{2}{|c|}{$40 \mathrm{~kg} \mathrm{~N} \mathrm{ha}^{-1}$} & \multicolumn{2}{|c|}{$0 \mathrm{~kg} \mathrm{~N} \mathrm{ha}^{-1}$} & \multicolumn{2}{|c|}{$40 \mathrm{~kg} \mathrm{~N} \mathrm{ha}^{-1}$} & \multicolumn{2}{|c|}{$0 \mathrm{~kg} \mathrm{~N} \mathrm{ha}^{-1}$} & \multicolumn{2}{|c|}{$40 \mathrm{~kg} \mathrm{~N} \mathrm{ha}^{-1}$} \\
\hline & $T(\mathrm{~mm})$ & $E(\mathrm{~mm})$ & $T(\mathrm{~mm})$ & $E(\mathrm{~mm})$ & $T(\mathrm{~mm})$ & $E(\mathrm{~mm})$ & $T(\mathrm{~mm})$ & $E(\mathrm{~mm})$ & $T(\mathrm{~mm})$ & $E(\mathrm{~mm})$ & $T(\mathrm{~mm})$ & $E(\mathrm{~mm})$ \\
\hline \multicolumn{13}{|l|}{ Chitala } \\
\hline Current & 84 & 235 & 159 & 223 & 92 & 240 & 198 & 219 & 101 & 248 & 216 & 218 \\
\hline+1 & 87 & 228 & 159 & 217 & 96 & 231 & 200 & 212 & 106 & 239 & 221 & 211 \\
\hline+3 & 94 & 225 & 170 & 215 & 106 & 226 & 212 & 210 & 117 & 232 & 235 & 209 \\
\hline+5 & 106 & 235 & 194 & 228 & 120 & 235 & 234 & 222 & 133 & 241 & 255 & 222 \\
\hline \multicolumn{13}{|l|}{ Makindu } \\
\hline Current & 57 & 158 & 100 & 167 & 64 & 167 & 100 & 167 & 70 & 177 & 109 & 174 \\
\hline+1 & 57 & 152 & 100 & 159 & 65 & 160 & 100 & 159 & 71 & 171 & 108 & 165 \\
\hline+3 & 59 & 147 & 103 & 154 & 66 & 152 & 103 & 154 & 73 & 161 & 108 & 158 \\
\hline+5 & 64 & 146 & 105 & 150 & 71 & 151 & 105 & 150 & 76 & 159 & 110 & 154 \\
\hline \multicolumn{13}{|l|}{ Katumani } \\
\hline Current & 56 & 227 & 104 & 229 & 61 & 248 & 116 & 248 & 68 & 268 & 126 & 263 \\
\hline+1 & 59 & 206 & 103 & 212 & 64 & 222 & 111 & 223 & 71 & 240 & 120 & 235 \\
\hline+3 & 61 & 180 & 99 & 182 & 68 & 190 & 110 & 195 & 74 & 207 & 116 & 202 \\
\hline+5 & 61 & 168 & 98 & 170 & 69 & 175 & 108 & 177 & 77 & 188 & 117 & 183 \\
\hline \multicolumn{13}{|l|}{ Betbridge } \\
\hline Current & 46 & 140 & 56 & 140 & 48 & 148 & 59 & 147 & 50 & 152 & 60 & 150 \\
\hline+1 & 47 & 140 & 55 & 139 & 49 & 147 & 59 & 147 & 51 & 153 & 60 & 150 \\
\hline+3 & 47 & 143 & 55 & 140 & 49 & 146 & 58 & 146 & 51 & 154 & 59 & 151 \\
\hline+5 & 48 & 147 & 54 & 142 & 51 & 153 & 57 & 151 & 52 & 156 & 58 & 154 \\
\hline
\end{tabular}



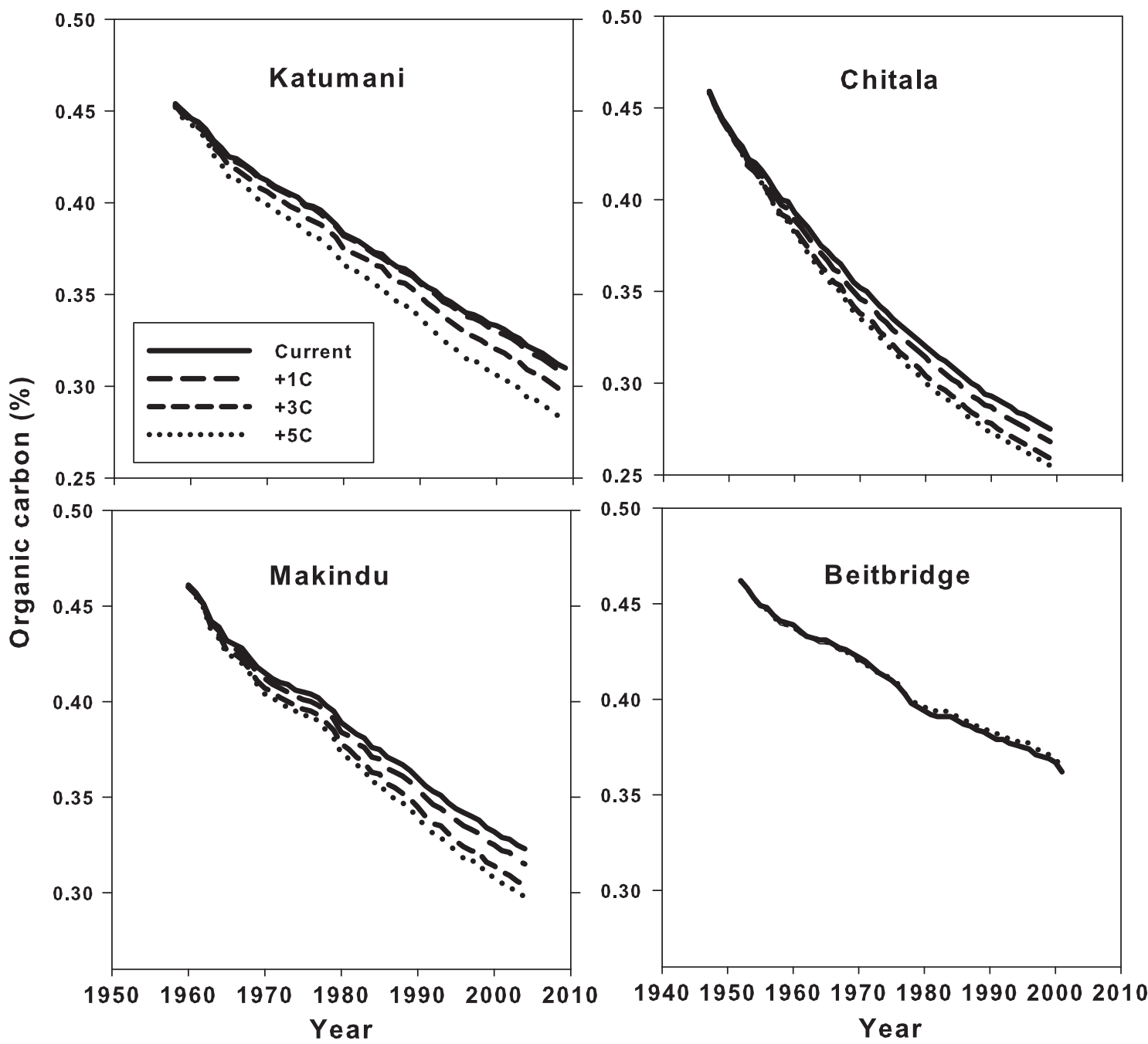

Fig. 4. Simulated change with time in soil organic carbon (\%) in the upper $0.15 \mathrm{~m}$ of soil growing a short-duration sorghum crop at current (solid line), $+1{ }^{\circ} \mathrm{C}$ (long dash line), $+3{ }^{\circ} \mathrm{C}$ (short dash line) and $+5{ }^{\circ} \mathrm{C}$ (dotted line) temperatures at four locations in Africa. At each location the starting level of soil organic carbon was set at $0.46 \%$ (Table 1 ).

soil organic carbon at different starting percentages. While the rate of decrease was slower with lower initial starting values, the results were similar to those in Fig. 4 in that the decrease was greater at the higher temperatures at all locations except at Beitbridge (data not shown). The breakdown of organic matter resulted in greater average annual nitrogen uptake by the sorghum with the rise in temperature at Katumani, Makindu and Chitala, but a decrease in uptake at Beitbridge in all three cultivars differing in time to flowering and maturity (Table 5 ). The warmer temperatures resulted in a decrease in the level of organic carbon in the soil (Fig. 4) that in the long term will reduce the mineralization of nitrogen and its uptake. The average figures in Table 5 hide a general decrease in nitrogen uptake with time from 40,32 , and $28 \mathrm{~kg} \mathrm{ha}^{-1}$ year $^{-1}$ in the first decade at Chitala, Makindu and Katumani to 14, 9 and $16 \mathrm{~kg} \mathrm{ha}^{-1} \mathrm{year}^{-1}$ in the fifth decade, respectively (data not shown). No consistent trend in nitrogen uptake in different decades was observed at Beitbridge. APSIM also enables the proportion of carbon in the different organic fractions to be simulated. We therefore did a sensitivity analysis of the effect of decreasing the proportion of organic carbon in the microbial biomass fraction. In the simulations, the initial proportion of organic carbon in the microbial biomass fraction was $0.040 \%$ and the inert fraction was $0.39 \%$ (Table 1 ); increasing the inert fraction at the expense of the biologically-active fraction slowed the breakdown of the organic matter and reduced the release of nitrogen (data not shown).
It also reduced the yield of sorghum, but the trends were similar and the boost to yield by the increase in temperature was also similar to that in Fig. 2 (data not shown).

Table 5

Mean simulated nitrogen uptake $\left(\mathrm{kg} \mathrm{ha}^{-1}\right.$ year $\left.^{-1}\right)$ by short-, medium-, and longduration cultivars of sorghum at current temperatures and with $1{ }^{\circ} \mathrm{C}, 2^{\circ} \mathrm{C}, 3{ }^{\circ} \mathrm{C}, 4^{\circ} \mathrm{C}$ and $5{ }^{\circ} \mathrm{C}$ increases in temperature at four locations in Africa. Data are averages for $\sim 50$ years of simulation.

\begin{tabular}{|c|c|c|c|c|c|c|}
\hline & Current & $+1{ }^{\circ} \mathrm{C}$ & $+2{ }^{\circ} \mathrm{C}$ & $+3{ }^{\circ} \mathrm{C}$ & $+4^{\circ} \mathrm{C}$ & $+5^{\circ} \mathrm{C}$ \\
\hline \multicolumn{7}{|c|}{ Short duration } \\
\hline Chitala & 23.55 & 24.24 & 24.87 & 25.39 & 25.80 & 26.13 \\
\hline Makindu & 24.25 & 25.22 & 25.98 & 26.59 & 27.04 & 27.35 \\
\hline Katumani & 20.88 & 21.33 & 21.93 & 22.72 & 23.56 & 24.36 \\
\hline Beitbridge & 14.19 & 13.90 & 13.43 & 12.77 & 11.90 & 11.37 \\
\hline \multicolumn{7}{|c|}{ Medium duration } \\
\hline Chitala & 23.08 & 23.75 & 24.34 & 24.86 & 25.27 & 25.64 \\
\hline Makindu & 23.41 & 24.15 & 24.98 & 25.70 & 26.34 & 26.50 \\
\hline Katumani & 20.96 & 21.12 & 21.54 & 22.23 & 22.86 & 23.62 \\
\hline Beitbridge & 12.20 & 12.03 & 11.77 & 11.50 & 10.81 & 10.01 \\
\hline \multicolumn{7}{|c|}{ Long duration } \\
\hline Chitala & 22.78 & 23.40 & 23.97 & 24.46 & 24.93 & 25.30 \\
\hline Makindu & 22.53 & 23.14 & 23.82 & 24.33 & 24.85 & 25.14 \\
\hline Katumani & 20.96 & 21.32 & 21.31 & 21.65 & 22.21 & 22.68 \\
\hline Beitbridge & 11.00 & 10.93 & 10.78 & 10.38 & 10.06 & 9.70 \\
\hline
\end{tabular}


3.6. Predicted effects of plant population, fertilization and increasing temperatures on yield

An alternative management tool to maintain yields with climate change is to alter the population density. An increase in the population density may reduce the loss of water by soil evaporation and increase water use efficiency during the season. On the other hand, if yields are reduced as a result of water shortage, particularly during seed filling, decreasing the planting density should benefit yield. At Chitala, Katumani and Makindu, with no additional nitrogen, increasing the plant population from the standard plant population of $66,000-80,000$ plants $\mathrm{ha}^{-1}$ decreased yields or had no effect on yields at current temperatures and when temperatures were increased by $3{ }^{\circ} \mathrm{C}$, but at Beitbridge yields were increased (Table 6). Decreasing the plant population with current farm practice increased yields at Makindu and Beitbridge, but this increase diminished as temperatures increased. When $20 \mathrm{~kg} \mathrm{ha}^{-1}$ of nitrogen was applied, increasing the plant population from 66,000 to 80,000 plants ha ${ }^{-1}$ resulted in a decrease in yield at Chitala and Makindu, no change in yield at Katumani and an increase in yield at Beitbridge, while decreasing the population from 66,000 to 50,000 plants ha ${ }^{-1}$ decreased the yield at Chitala and Makindu at current temperatures and with a $3{ }^{\circ} \mathrm{C}$ rise in temperature, but increased yields at Beitbridge (Table 6 ).

\section{Discussion}

There is widespread agreement that in the tropics, sub-tropics and Mediterranean climatic zones, yields will decrease with the warming associated with climate change, which contrasts with the increased yields with global warming at higher latitudes ( per et al., 2009; Yadav et al., 2011; Turner and Meyer, 2011). At high nitrogen application levels similar to those used in commercial practice, the present simulation study showed that the mean yields of sorghum decreased with global warming at the two warmer sites, Chitala and Beitbridge, but did not change or increased at the two cooler sites in Kenya. However, the unexpected result from the study was that using cultivars of similar maturity and a fertilizer level similar to the unfertilized levels of small-holder farmers in sub-Saharan Africa, the effect of global warming was to increase the mean yields at all locations (Table 3 ) and in all except the lowyielding (driest) years (Figs. 1 and 2). Our analysis suggests that this increase in yield results from an increase in the mineralization of soil organic matter at higher temperatures, and from the increase in water use by transpiration and a decrease in the proportion of water lost by soil evaporation. The higher temperatures increased the rate of mineralization of organic matter, as shown by the increased rate of the decline in soil organic carbon (Fig. 4), and increased the uptake by the sorghum crop of nitrogen from the soil (Table 5). However, this yield boost from the warmer temperatures is likely to be limited as the increased loss of soil organic carbon will reduce the amount of nitrogen mineralization and reduce the nitrogen available to the crop. This was clear as the analysis showed less soil nitrogen uptake in the fifth decade compared with the first decade after an increase in temperature.

What our analysis also demonstrates is that the application of a micro-dose of nitrogen $\left(20 \mathrm{~kg} \mathrm{ha}^{-1}\right)$ markedly increased the mean yields of the short-duration sorghum by $40 \%$ to $70 \%$ at the wetter sites and by $15 \%$ at the very dry site when the temperatures increased by $3{ }^{\circ} \mathrm{C}$ (Fig. 2). The additional nitrogen reduced the proportion of water loss by soil evaporation and increased water use by the crop in transpiration and substantially increased the harvest index of the crop. Thus, while yields may decrease with global warming when the sorghum is fertilized, the increased yields from the use of fertilizer more than makes up for the changes in yield associated with global warming in the unfertilized sorghum.

We used the simulation to explore other ways of maintaining yields with global warming. Using longer-season cultivars reduced yields at all four locations, unless high levels of nitrogen were applied when longer-duration cultivars increased yields at Chitala (Table 3). We conclude that for small-holder farmers the current short-season cultivars will still be required with global warming, even though this may limit yields in very good rainfall seasons (Fig. 3). With current small-holder management practices, decreasing the plant population from the current 66,000 plants $^{-1}$ to

Table 6

Simulated average yields $\left(\mathrm{kg} \mathrm{ha}^{-1}\right)$ of a short-duration cultivar of sorghum at three plant populations $\left(50,000,66,000\right.$ and 80,000 plants ha $\left.{ }^{-1}\right)$ at current temperatures, with 1,3 and $5{ }^{\circ} \mathrm{C}$ increases in temperature and 0,20 and $80 \mathrm{~kg} \mathrm{ha}^{-1}$ of nitrogen fertilizer at four sites in Africa. Data are averages for $\sim 50$ years of simulation.

\begin{tabular}{|c|c|c|c|c|c|c|c|c|c|}
\hline \multirow[t]{2}{*}{ Temperature regime $\left({ }^{\circ} \mathrm{C}\right)$} & \multicolumn{3}{|c|}{50,000 plants ha ${ }^{-1}$} & \multicolumn{3}{|c|}{66,000 plant ha ${ }^{-1}$} & \multicolumn{3}{|c|}{80,000 plant ha $^{-1}$} \\
\hline & $0 \mathrm{~kg} \mathrm{~N}$ & $20 \mathrm{~kg} \mathrm{~N}$ & $80 \mathrm{~kg} \mathrm{~N}$ & $0 \mathrm{~kg} \mathrm{~N}$ & $20 \mathrm{~kg} \mathrm{~N}$ & $80 \mathrm{~kg} \mathrm{~N}$ & $0 \mathrm{~kg} \mathrm{~N}$ & $20 \mathrm{~kg} \mathrm{~N}$ & $80 \mathrm{~kg} \mathrm{~N}$ \\
\hline \multicolumn{10}{|l|}{ Chitala } \\
\hline Current & 1577 & 2582 & 3733 & 1660 & 3022 & 4803 & 1557 & 2763 & 4714 \\
\hline+1 & 1571 & 2532 & 3669 & 1680 & 2893 & 4769 & 1384 & 2717 & 4647 \\
\hline+3 & 1578 & 2503 & 3488 & 1716 & 2907 & 4683 & 1576 & 2692 & 4558 \\
\hline+5 & 1598 & 2473 & 3243 & 1759 & 2913 & 4425 & 1666 & 2686 & 4306 \\
\hline \multicolumn{10}{|l|}{ Makindu } \\
\hline Current & 1833 & 2063 & 2143 & 1736 & 2565 & 3051 & 1673 & 2516 & 3178 \\
\hline+1 & 1849 & 2124 & 2200 & 1792 & 2579 & 3175 & 1714 & 2541 & 3308 \\
\hline+3 & 1871 & 2188 & 2300 & 1843 & 2579 & 3268 & 1747 & 2533 & 3351 \\
\hline+5 & 1859 & 2101 & 2190 & 1856 & 2524 & 3086 & 1767 & 2478 & 3167 \\
\hline \multicolumn{10}{|l|}{ Katumani } \\
\hline Current & 1343 & 2385 & 2577 & 1195 & 2368 & 2627 & 1222 & 2406 & 2841 \\
\hline+1 & 1499 & 2443 & 2628 & 1378 & 2446 & 2587 & 1384 & 2434 & 2828 \\
\hline+3 & 1646 & 2472 & 2656 & 1588 & 2554 & 2757 & 1576 & 2526 & 3001 \\
\hline+5 & 1686 & 2462 & 2816 & 1710 & 2507 & 2956 & 1666 & 2514 & 3113 \\
\hline \multicolumn{10}{|l|}{ Beitbridge } \\
\hline Current & 826 & 921 & 1027 & 795 & 899 & 980 & 821 & 967 & 1039 \\
\hline+1 & 796 & 879 & 955 & 767 & 838 & 924 & 798 & 897 & 1001 \\
\hline+3 & 672 & 784 & 809 & 641 & 740 & 796 & 672 & 808 & 836 \\
\hline+5 & 515 & 606 & 620 & 510 & 549 & 580 & 538 & 609 & 623 \\
\hline
\end{tabular}


50,000 plants ha ${ }^{-1}$ will increase yields on average at all except the wettest site (Chitala), while increasing the plant population to 80,000 plants ha ${ }^{-1}$ had little effect on average yields at current temperatures (Table 6 ). With addition of a small amount of fertilizer $\left(20 \mathrm{~kg} \mathrm{~N} \mathrm{ha}^{-1}\right)$, decreasing the plant population decreased yields even more at the wettest site, but increased yields at Beitbridge, the driest site (Table 6). With global warming, decreasing the plant population or increasing the plant population did not change the response, whether positive or negative, at all levels of fertilization (Table 6). We conclude that with the short-duration cultivar, the plant population of 66,000 plants ha $^{-1}$ suits the present conditions at all sites except Beitbridge and changing the plant population with global warming will not have great benefits to the increases in yield at current levels of fertilizer use or in overcoming the decreases in yield at higher levels of fertilization.

Cooper et al. (2009) reported on a simulation study of sorghum in India in which the yields, estimated with the Decision Support System for Agro-technology Transfer (DSSAT) model which is similar to the APSIM model used in this study, decreased with increasing temperature. Indeed, similar decreases in yield were observed in short-duration pigeon pea [Cajanus cajan (L.) Millsp.], maize, pearl millet [Pennisetum glaucum (L.) R. Br.] and peanut (Cooper et al., 2009). The simulations in Cooper et al. (2009) were all run with nutrients non-limiting (equivalent to at least $40 \mathrm{~kg} \mathrm{~N}^{-1}$ in our study), confirming the observed lower yields with global warming simulated by the present study. However, our simulation clearly predicts an increase in mean yields with rising temperatures at low levels of nitrogen fertilizer, so that small-holder farmers are unlikely to be more vulnerable to climate change in the short term. However, if they are to overcome malnutrition, yields will need to increase and this study shows that small doses of nitrogen can markedly increase yields, but with a slightly increased risk of crop failure. Moreover, with increased levels of applied nitrogen, rising temperatures will reduce yields particularly in drier years, but mean yields with additional nitrogen will still be substantially higher than with traditional fertilizer levels.

\section{Acknowledgements}

NCT thanks ICRISAT in Nairobi and particularly Drs. Said Silim and Peter Cooper for arranging financial support for this project. We thank Dr. John Dimes for initiating some of the runs with an earlier version of APSIM-Sorghum and Anthony Oyoo for technical support with APSIM-Sorghum.

\section{References}

Carberry, P.S., Muchow, R.C., Hammer, G.L., 1993. Modelling genotypic and environmental control of leaf area dynamics in grain sorghum. II. Individual leaf level. Field Crops Res. 33, 311-328.

Christensen, J.H., Hewitson, B., Busuioc, A., Chen, A., Gao, X., Held, I., Jones, R., Kolli, R.K., Kwon, W.-T., Laprise, R., Magaña Rueda, V., Mearns, L., Menéndez, C.G. Räisänen, J., Rinke, A., Sarr, A., Whetto, P., 2007. Regional climate projections. In Solomon, S., Qin, D., Manning, M., Marquis, M., Averyt, K.B., Tignor, M., Miller H.L. (Eds.), Climate Change 2007: The Physical Science Basis. Contribution of Working Group I to the Fourth Assessment Report of the Intergovernmental Panel on Climate Change. Cambridge University Press, Cambridge, UK, and New York, NY, USA.

Cooper, P., Rao, K.P.C., Singh, P., Dimes, J., Traore, P.S., Rao, K., Dixit, P., Twomlow, S.I., 2009. Farming with current and future climate risk: Advancing a 'Hypothesis of Hope' for rainfed agriculture in the semi-arid tropics. J. SAT Agric. Res. 7, 1-19.

Cure, J.D., Acock, B., 1986. Crop responses to carbon dioxide doubling: a literature survey. Agric. For. Meteor. 38, 127-145.

FAOSTAT-Agriculture, 2010. <http://faostat.fao.org> (accessed May 2012).

Hammer, G.L., Carberry, P.S., Muchow, R.C., 1993. Modelling genotypic and environmental control of leaf area dynamics in grain sorghum. I. Whole plant level. Field Crops Res. 33, 293-310.
Hammer, G.L., van Oosterom, E., McLean, G., Chapman, S.C., Broad, I., Harland, P., Muchow, R.C., 2010. Adapting APSIM to model the physiology and genetics of complex adaptive traits in field crops. J. Exp. Bot. 61, 2185-2202.

Hansen, J.W., Mishra, A., Rao, K.P.C., Indeje, M., Ngugi, R.K., 2009. Potential value of GCM-based seasonal rainfall forecasts for maize management in semi-arid Kenya. Agric. Syst. 101, 80-90.

Hatfield, J., Boote, K. Fay, P. Hahn, L. Izaurralde, C., Kimball, B.A., Mader, T. Morgan, J., Ort, D., Polley, W., Thomson, A., Wolfe, D., 2008. Agriculture. In: The Effects of Climate Change on Agriculture, Land Resources, Water Resources, and Biodiversity. A Report by the U.S. Climate Change Science Program and the Subcommittee on Global Change Research. Washington, DC, USA, 362pp. <http://www.sap43.ucar.edu/documents/SAP_4.3_6.18.pdf >

Hulme, M., Doherty, R., Ngara, T., New, M., Lister, D., 2001. African climate change: 1900-2100. Clim. Res. 17, 145-168.

ICPAC, 2007. Climate Change and Human Development in Africa: Assessing the Risks and Vulnerability of Climate Change in Kenya, Malawi and Ethiopia. Draft Report by the Intergovernmental Authority on Development (IGAD) Climate Prediction and Applications Centre (ICPAC), May 2007. Occasional Paper, Human Development Report 2007/2008. United Nations Development Program, 57pp.

Jaetzold, R., Schmidt, H., Hornetz, B., Shisanya, C., 2006. Farm Management Handbook, vol. 2. Part C. East Kenya, Subpart C1, Eastern Province, second ed. Ministry of Agriculture, Nairobi, Kenya. <http://www2.gtz.de/dokumente/bib/ 07-1286.pdf>

Jones, P.G., Thornton, P.K., 2003. The potential impacts of climate change on maize production in Africa and Latin America in 2055. Global Environ. Change 13, 5159.

Keating, B.A., Carberry, P.S., Hammer, G.L., Probert, M.E., Robertson, M.J., Holzworth, D., Huth, N.I., Hargreaves, J.N.G., Meinke, H., Hochman, Z., McLean, G., Verburg K., Snow, V., Dimes, J.P., Silburn, M., Wang, E., Brown, S., Bristow, K.L., Asseng, S., Chapman, S., McCown, R.L., Freebairn, D.M., Smith, C.J., 2003. An overview of APSIM, a model designed for farming systems simulation. Eur. J. Agron. 18, 267 288.

Lobell, D.B., Burke, M.B., Tebaldi, C., Mastrandrea, M.D., Falcon, W.P., Naylor, R.L. 2008. Prioritizing climate change adaptation needs for food security in 2030 . Science 319, 607-610.

MacCarthy, D.S., Sommer, R., Vlek, P.G., 2009. Modeling the impacts of contrasting nutrient and residue management practices on grain yield of sorghum (Sorghum bicolor (L.) Moench) in a semi-arid region of Ghana using APSIM. Field Crops Res. 113, 105-115.

MacCarthy, D.S., Vlek, P.G., Batiano, A., Tabo, R., Fosud, M., 2010. Modeling nutrient and water productivity of sorghum in smallholder farming systems in a semiarid region of Ghana. Field Crops Res. 118, 251-258.

Ncube, B. Dimes, J.P., van Wijk, M.T., Twomlow, S.J., Giller, K.E., 2009. Productivity and residual benefits of grain legumes to sorghum under semi-arid condition in south-western Zimbabwe: unravelling the effects of water and nitrogen using a simulation model. Field Crops Res. 110, 173-184.

New, M., Hewitson, B., Stephenson, D.B., Tsiga, A., Kruger, A., Manhique, A., Gomez B., Coelho, C.A.S., Bulane, L., Fortunata, L., Mdoka, M.L., Lajoie, R., 2006. Evidence of trends in daily climate extremes over southern and west Africa. J. Geophy. Res. 111, D14102. http://dx.doi.org/10.1029/2005JD006289.

Okwach, G.E., Simiyu, C.S., 1999. Evaluation of long-term effects of management on and productivity in a semi-arid area of Kenya using simulation models. E. Afr. Agric. For. J. 65, 143-155.

Ottman, M.J., Kimball, B.A., Pinter, P.J., Wall, G.W., Vanderlip, R.L., Leavitt, S.W., LaMorte, R.L., Matthias, A.D., Brooks, T.J., 2001. Elevated $\mathrm{CO}_{2}$ increases sorghum biomass under drought conditions. New Phytol. 15, 261-273.

Prasad, P.V.V., Boote, K.J., Allen Jr., L.H., 2006. Adverse high temperature effects on pollen viability, seed-set, seed yield and harvest index of grain-sorghum Sorghum bicolor (L.) Moench] are more severe at elevated carbon dioxide due to high tissue temperature. Agric. For. Meteorol. 139, 237-251.

Seneweera, S., Norton, R.M., 2011. Plant responses to increased carbon dioxide. In: Yadav, S.S., Redden, R.J., Hatfield, J.L., Lotze-Campen, H., Hall, A.E. (Eds.) Crop Adaptation to Climate Change. Wiley/Blackwell, Chichester, UK, pp. 198-217.

Tadross, M., Suarez, P., Lotsch, A., Hachigonta, S., Mdoka, M., Unganai, L., Lucio, F. Kamdonyo, D., Muchinda, M., 2007. Changes in growing-season rainfall characteristics and downscaled scenarios of change over southern Africa: implications for growing maize. In: IPCC Regional Expert Meeting on Regional Impacts, Adaptation, Vulnerability, and Mitigation, Nadi, Fiji, June 20-22, pp. 193-204.

Turner, N.C., Meyer, R., 2011. Synthesis of regional impacts and global agricultura adjustments. In: Yadav, S.S., Redden, R. Hatfield, J.L, Lotze-Campen, $\mathrm{H}$., Hall, A.E. (Eds.), Crop Adaptation to Climate Change. Wiley/Blackwell, Chichester, UK, pp. $156-165$.

Turner, N.C., Molyneux, N., Yang, S., Xiong, Y.-C., Siddique, K.H.M., 2011. Climate change in south-west Australia and north-west China: challenges and opportunities for crop production. Crop Pasture Sci. 62, 445-456.

Visser, M.E., Both, C., 2005. Shifts in phenology due to global climate change: the need for a yardstick. Proc. Roy. Soc. B Biol. Sci. 272, 2561-2569.

Yadav, S.S., Redden, R.J., Hatfield, J.L., Lotze-Campen, H., Hall, A.E., 2011. Crop Adaptation to Climate Change. Wiley/Blackwell, Chichester, UK, 632pp.

World Bank, 2007. Agriculture for Development - World Development Report 2008 365pp. 